ISSN: 0213-2079 - ISSN electrónico: 2386-3889

DOI: https://doi.org/10.14201/shhmo2019411353377

\title{
LA CONSTRUCCIÓN DE LA IMAGEN REGIA DE MARÍA LUISA DE ORLEANS
}

\section{The building of the royal image of Maria Luisa de Orleans}

\section{Ezequiel BORGOGNONI}

Universidad de Buenos Aires - Universidad Católica Argentina - CONICET

Correo-e.: eborgognoni@gmail.com

RESUMEN: La España de Carlos II y María Luisa de Orleans era una sociedad de príncipes, como magistralmente lo ha explicado Lucien Bely, y en ella tanto la reputación social como la autoridad política de los reyes se representaban a través de símbolos externos que actuaban como indicadores del status. Entre ellos, la vestimenta era uno de los más importantes y servía a los fines de la construcción de la imagen regia. La Monarquía, en su afán de consolidar la autoridad soberana del monarca, intervino activamente en la definición de la imagen real. Pero la construcción de la majestad no implicó únicamente al monarca ya que se hizo extensiva a su reina consorte. En este trabajo, analizaremos los fundamentos, alcances y limitaciones en la construcción de la imagen de la reina María Luisa de Orleans o, lo que es lo mismo, el inacabado proceso de hispanización de una reina católica.

Palabras clave: Imagen regia; identidad; influencias francesas; vestido femenino; María Luisa de Orleans.

ABSTRACT: The Spain of Carlos II and Maria Luisa de Orleans was a society of princes, as Lucien Bely has brilliantly explained it, and in it both the social reputation and the political authority of the kings were represented through external symbols that acted as indicators of the status. Among them, clothing was one of the most important and served the purpose of building the regal image. The Monarchy, in its eagerness to consolidate the sovereign authority of the king, intervened actively

Ediciones Universidad de Salamanca / @@ Stud. his., H. ${ }^{a}$ mod., 41, n. 1 (2019), pp. 353-377 
in the definition of the real image. But the construction of majesty did not imply only the king since it was extended to his queen consort. In this paper, we will analyze the foundations, scope and limitations in the construction of the image of Queen Maria Luisa de Orleans or, what is the same, the unfinished process of Hispanicization of a Catholic queen.

Keywords: Royal image; identity; French influences; feminine dress; Maria Luisa de Orleans.

\section{INTRODUCCIÓN}

Las monarquías del barroco fueron el escenario de un conjunto de discursos y prácticas que tuvieron como finalidad afianzar la autoridad de sus reyes y consolidar la posición de la dinastía. En el mundo de la corte, la producción de imágenes bidimensionales y tridimensionales sirvió a estos propósitos ${ }^{1}$. Restringiendo nuestra mirada al aspecto indumentario femenino de la reina de España, analizaremos como se proyectó y llevó a la práctica la construcción de la imagen de la reina María Luisa de Orleans. Este estudio será realizado a la luz de un corpus documental heterogéneo. Analizaremos las relaciones francesas y españolas de la época que se escribieron con motivo del matrimonio entre la princesa de Orleans y el joven monarca español. A este tipo de fuente sumaremos algunos documentos obtenidos en el Archivo General de Palacio. Además, tanto las relaciones de madame d'Aulnoy como la correspondencia de madame de Villars nos permitirán conocer ciertos rasgos de la personalidad y los gustos estéticos de la soberana. Finalmente, estas fuentes documentales serán comparadas con algunas de las representaciones artísticas más afamadas de la reina con el propósito de advertir el discurso visual que se intentó transmitir desde la corte.

Para empezar, partimos de una serie de premisas fundamentales. En primer lugar, señalamos que la construcción de la imagen real se sustentó en mecanismos políticos y dispositivos culturales visuales y textuales, y que lejos de ser estos excluyentes, actuaron operativamente de manera complementaria. En este sentido, la historia política, la historia social y la historia del arte deben actuar de manera mancomunada para que podamos comprender los diferentes usos y funciones que configuraron ciertas imágenes que se transformaron en un poderoso instrumento de persuasión y propaganda ${ }^{2}$. En segundo lugar, consideramos importante subrayar que el cuerpo

1. BOUZA ÁlVAREZ, F.: Palabra e imagen en la Corte. Cultura oral y visual de la nobleza en el Siglo de Oro. Madrid, 2003.

2. MCGLYNN, S. and WOODACRE, E. (eds.): The Image and Perception of Monarchy in Medieval and Early Modern Europe. Newcastle, 2014. 
político de la monarquía no puede identificarse únicamente con el cuerpo natural del rey, sino que ha de extenderse a la reina ${ }^{3}$. Si bien la imagen real de Carlos II y la de su madre Mariana de Austria han recibido notable atención, los especialistas no se han detenido todavía en el estudio de la imagen de sus reinas consortes ${ }^{4}$. En tercer lugar, creemos que el estudio de la vestimenta es esencial para comprender la configuración de la imagen real y que las decisiones indumentarias de los reyes deben ser leídas en clave política ${ }^{5}$. La imagen de la reinas estaba estrechamente vinculada a su indumentaria y la camarera mayor, en tanto autoridad máxima de la cámara, actuaba como guardiana de una rígida etiqueta palatina que se enfocaba en la hispanización de las princesas de las otras cortes europeas que llegaban a la Monarquía hispana para casarse con el rey católico ${ }^{6}$. Si nos limitamos al análisis de las representaciones artísticas de María Luisa de Orleans realizadas por Francisco Rizi y José García Hidalgo, estaríamos en condiciones de concluir que la hispanización de la joven francesa fue completa y exitosa. No obstante, es importante advertir que estas obras tuvieron una fuerte intencionalidad propagandística. Los intentos por ofrecer la imagen de una reina hispanizada apenas pudieron ocultar y velar una realidad que se hace presente al consultar otras fuentes de naturaleza diversa en donde se advierte la propia agencia de María Luisa en todo este proceso.

\section{MODA E IMPERIO: DE MADRID A VERSALLES}

El debut de España como centro creador en el mundo de la moda se originó en tiempos de los Reyes Católicos y se consolidó en los reinados de Carlos V y Felipe

3. EARENFIGHT, T.: The King's Other Body. Maria of Castile and the Crown of Aragon. Philadelphia, 2010, pp. 131-144.

4. Me remito, sin ánimos de exhaustividad, a los últimos trabajos publicados sobre la imagen de Carlos II y Mariana de Austria: PASCUAL CHENEL, Á.: «La construcción visual de la imagen regia durante el reinado de Carlos II. Simulacros de Majestad y propaganda política» en GARCÍA GARCÍA, B. y ÁLVAREZ OSSORIO ALVARIÑO, A. (eds.): Visperas de Sucesión. Europa y la Monarquía de Carlos II. Madrid, 2015, pp. 297-331. LLORENTE, M.: «Mariana of Austria's Portraits as Ruler-Governor and Curadora by Juan Carreño de Miranda and Claudio Coello» in CRUZ, A. J. and STAMPINO, M. G. (eds.): Early Modern Habsburg Women: Transnational Contexts, Cultural Conflicts, Dynastic Continuitie. Farnham, 2013. RODRÍGUEZ DE CEBALLOS, A.: «Retrato de Estado y propaganda política: Carlos II (en el tercer centenario de su muerte)", Anuario del Departamento de Historia y Teoría del Arte, 12, 2000, pp. 93-109.

5. LOZANO, J. S.: «Ser vistas, hacerse mirar. Modelos visuales de feminidad regia en la Europa del Renacimiento» en RÍOS LLORET, R. E; VILAPLANA SANCHIS, S. et all (eds.): Germana de Foix i la societat cortesana del seu temps. Valencia, 2006. ARIBAUD, C. et MOUYSSET, S. (eds.): Vêture et pouvoir: XIIIe-XIXe siècles. Toulouse, 2003. ROCHE, D.: A History of Everyday Things. Cambridge, 2000.

6. VALGOMA y DÍAZ-VARELA, D. de la.: Norma y ceremonia de las reinas de la Casa de Austria. Madrid, 1958. 
$\mathrm{II}^{7}$. Coincidiendo con la preponderancia política alcanzada por el Imperio, el atuendo español lideró la moda europea del siglo XVI y terminó imponiéndose tanto en los virreinatos españoles como en otras cortes europeas ${ }^{8}$. Los Habsburgo de Madrid y Viena se transformaron en los adalides del color negro, expresión de la piedad cristiana y las virtudes morales'. El negro había sido el color de la etiqueta de los duques de Borgoña, la cual fue introducida oficialmente en España en 1548. Grazietta Butazzi ha documentado la propensión monocromática de Carlos $\mathrm{V}$ a través del estudio de las relaciones de viaje y entradas triunfales en sus dominios ${ }^{10}$. La preferencia del emperador por los trajes negros se constata en sus retratos oficiales: el de Christoph Amberger ${ }^{11}$, el de Lucas Cranach el Viejo ${ }^{12}$ y el de Francesco Terzio ${ }^{13}$, entre otros. No es de extrañar que, a imitación de la imagen del emperador, sus consejeros, agentes y miembros destacados de la corte también adoptaran dicho color ${ }^{14}$. Para la época de Felipe II contamos con numerosos testimonios documentales y visuales que demuestran la preferencia cromática del rey ${ }^{15}$. Cuando todavía era un príncipe y se acordó su matrimonio con María Tudor, Felipe viajó a Inglaterra y se presentó ante la corte

7. DESCALZO, A.: «El traje masculino español en la época de los Austrias» en COLOMER, J. L y DESCALZO, A. (dirs.): Vestir a la española en las cortes europeas (siglos XVI y XVII). Madrid, 2014, pp. 15-38. BERNIS, C.: «La moda en la España de Felipe II a través del retrato de Corte» en SERRERA, J. M. (ed.): Alónso Sánchez Coello y el retrato en la Corte de Felipe II. Madrid, 1991, pp. 66-111. Ibídem, Trajes y modas en la España de los Reyes Católicos, 2 vols. Madrid, 1978-1989. Ibídem, Indumentaria española en tiempos de Carlos V. Madrid, 1962.

8. GUARINO, G.: «Modas españolas y leyes suntuarias en la Italia de los Austrias» en COLOMER, J. L y DESCALZO, A. (dirs.): Vestir a la española en las cortes europeas (siglos XVI y XVII). Madrid, 2014, pp. 233-250. HAJNÁ, M.: «Moda al servicio del poder. La vestimenta en la sociedad noble de la Europa Central de la Edad Moderna y la influencia de España» en CABAÑAS BRAVO, M, LÓPEZ YARTO ELIZALDE, A y RINCÓN GARCÍA, W. (coords.): Arte, poder y sociedad en la España de los siglos XV a XX. Madrid, 2007, pp. 71-82.

9. JOLIVET, S.: «La construction d'une image: Philippe le Bon et le noir (1419-1467)», Apparence (s), 6, 2015, pp. 1-35.

10. BUTTAZZI, G.: «Intorno al Cavalliere in nero: note sulla moda maschile tra Cinquecento e Seicento», in ZANNI, A e DI LORENZO, A (eds.) Giovanni Battista Moroni: Il Cavaliere in nero. Milano, 2005, pp. 47-55.

11. Christoph Amberger, Kaiser Karl V, 1532, óleo sobre tabla 67,2 x 50, 7 cm. Berlín, Gemäldegalerie.

12. Lucas Cranach el Viejo, Retrato del emperador Carlos V, 1533, óleo sobre tabla 51,2 x $36 \mathrm{~cm}$. Madrid, Museo Thyssen Bornemisza.

13. Francesco Terzio, Kaiser Karl V, 1550, óleo sobre lienzo 204 x 208 cm. Viena, Kunsthistorisches Museum.

14. COLOMER, J.L.: «El negro y la imagen real» en COLOMER, J. L y DESCALZO, A (dirs.): Vestir a la española en las cortes europeas (siglos XVI y XVII). Madrid, 2014, p.82.

15. Me remito al trabajo de Carmen Bernis sobre la moda en la España de Felipe II citado en la nota 7.

Ediciones Universidad de Salamanca / అ@@ Stud. his., H. ${ }^{a}$ mod., 41, n. 1 (2019), pp. 353-377 
foránea vestido completamente en terciopelo negro ${ }^{16}$. Las representaciones artísticas de Antonio Moro ${ }^{17}$ quien lo pintó vestido de terciopelo negro y raso blanco, y la de Sofonisba Anguissola, quien retrató al monarca enteramente de negro, confirman la predilección monocromática del $\mathrm{rey}^{18}$. Es importante destacar que la Monarquía hispana recibía los tintes del Nuevo Mundo y de esta forma lograba conseguir un negro intenso, denominado en la época «ala de cuervo» ${ }^{19}$.

El siglo XVII se inició sin apenas cambios estilísticos ${ }^{20}$. Pero a medida que avanzaba la centuria la Monarquía hispana perdía su antigua reputación, aspecto que se haría extensivo al terreno de la moda. En 1621, la Junta de Reformación lanzó nuevas disposiciones legales para limitar los gastos en trajes y vestidos. Entre los hombres de la corte, se hizo extensivo el uso de calzones y golillas mientras que las mujeres apostaron a los últimos verdugados y a los guardainfantes ${ }^{21}$ Por entonces, podamos observar que la moda española evolucionaba hacia la sencillez y la austeridad a contrapelo de lo que sucedía en Francia. Tras la firma del Tratado de los Pirineos (1659), que supuso la paz para las monarquías francesa y española, la moda comenzó a imponerse desde la capital del reino vencedor: Versalles. En las décadas de 1660 y 1670, las influencias de la moda francesa comenzaron a sentirse en la corte española ${ }^{22}$. Ariana Giorgi postula una decadencia del modelo español que sucumbe ante la etiqueta francesa ${ }^{23}$. En Madrid, la introducción del traje francés fue promovida por Juan José de Austria y otros personajes importantes, como el marqués de Frómista y Caracena, a sabiendas del impacto político y cultural que esto provocaba.

Durante el reinado de Carlos II, el traje genuinamente español coexistió con prendas de inspiración francesa. En las cuentas del guardarropas del rey, aparecen

16. MUÑZ, A.: Sumaria y verdadera relación del buen viaje que el buen príncipe de las Españas don Felipe hizo a Inglaterra. Zaragoza, 1554.

17. Antonio Moro, Felipe II, 1550, óleo sobre tabla 107,5 x 83,3 cm Bilbao. Museo de Bellas Artes.

18. Sofonisba Anguissola, Felipe II, 1565, óleo sobre lienzo 88 x $72 \mathrm{~cm}$. Madrid, Museo del Prado.

19. ROQUERO, A.: Tintes y tintoreros de América: catálogo de materias primas y registro etnográfico de México, Centro América, Andes Centrales y Selva amazónica. Madrid, 2006, pp. 122-127. SÁNCHEZ ORTIZ, A.: «El color: símbolo de poder y orden social. Apuntes para una historia de las apariencias en Europa», Espacio, Tiempo y Forma, Serie IV, H. Moderna, 12, 1999, pp. 321-354.

20. BERNIS, C.: El traje y los tipos sociales en el Quijote. Madrid, 2001.

21. SEMPERE Y GUARINOS, J.: Historia del lujo y de las leyes suntuarias en España. Madrid, 1788, pp. 120-121.

22. DESCALZO, A.: El retrato y la moda en España (1661-1746). Tesis doctoral inédita, Madrid, Universidad Autónoma de Madrid, 2004.

23. GIORGI, A.: España viste a la francesa. La bistoria de un traje de moda de la segunda mitad del siglo XVII. Murcia, 2016. 
diferenciados, por primera vez, el vestido «a la española» del vestido «a la moda», haciendo este último alusión a prendas francesas ${ }^{24}$. En ningún caso se trató de una eliminación completa del atuendo español. Carlos continuó utilizando traje de golilla y la reina vestía típicos trajes «a la española», apretados de la cintura para arriba y anchos de la cintura para abajo. Sin embargo, lo característico del período es la convivencia de elementos españoles tradicionales con los franceses. El aspecto indumentario de la reina María Luisa de Orleans, una princesa de ascendencia francesa, refleja a la perfección la hibridación estética antes referida. La reina aceptó las costumbres y modas española y, al mismo tiempo, se las ingenió para dejar patente su ascendencia. Sus trajes aunaron tanto elementos franceses como españoles. En esta investigación, analizaremos porqué la reina no estuvo dispuesta a renunciar a los estilos y tendencias de su país de origen y cómo esto afectó la construcción de la imagen real.

\section{LA FABRICACIÓN DE MARÍA LUISA DE ORLEANS: IMAGEN E IDENTIDAD POLÍTICA}

María Luisa de Orleans (París, 1662-Madrid, 1689) era la hija primogénita del duque Felipe I de Francia, hermano menor de Luis XIV de Francia, y de Enriqueta Ana de Inglaterra, hija del rey inglés Carlos I. Su infancia se desarrolló en el palacio de Saint Cloud, residencia de verano de sus padres, en compañía de sus ayas - la condesa de Saint Chaumont hasta 1669, y en lo sucesivo, la mariscala de Clérembault - y su hermana Ana María. Cuando María Luisa tenía ocho años, su madre falleció repentinamente y los rumores de envenenamiento no tardaron en expandirse por toda la corte. Al cabo de unos meses, el duque de Orleans se casó en segundas nupcias con Isabel Carlota, una princesa del Palatinado, y tuvo con ella tres hijos.

En la cuaresma de 1679, la joven María Luisa fue presentada oficialmente ante la corte francesa, ocasión que coincidió con la llegada a París de Pablo Spínola Doria, marqués de los Balbases y embajador del rey español, para la concertación del matrimonio con Carlos II. Dicha unión buscaba refrendar la paz de Nimega, firmada un año antes entre España y Francia, antiguos contendientes en las guerras de Holanda (1672-1678).

El matrimonio por poderes se celebró el 31 de agosto de 1679 en el castillo de Fontainebleau, donde el príncipe de Contí, Luis Armando de Borbón, representó a

24. Cuenta de las mercaderías que Juan Diez Rodera, Mercader de S. M. dio para servicio de S. M. y su R. persona para la Jornada que bizo a su feliz casamiento año de 1679. Archivo General de Palacio [AGP], Cuentas de particulares, leg. 323.

Ediciones Universidad de Salamanca / అ@@ Stud. his., H. ${ }^{a}$ mod., 41, n. 1 (2019), pp. 353-377 
Carlos II en el desposorio ${ }^{25}$. El periódico Mercure galant, publicación francesa que siguió muy de cerca los diferentes aspectos referidos a la boda y la posterior entrada de la reina en España, nos permite reconstruir cómo era el traje de bodas de María Luisa ${ }^{26}$. Al mismo tiempo, contamos con un grabado de Antoine Trouvain (16561708) de 1679 en donde puede verse a María Luisa el día de su casamiento luciendo un diseño típicamente francés y llevando en su cabeza una corona ${ }^{27}$.

El día de su boda, la reina llevaba un manto real violeta de larga cola, forrado de armiño, decorado con un ribete de tres filas de flores de lis en oro, ribeteadas por un parámetro de armiño de $12,5 \mathrm{~cm}$ de anchura; un vestido del mismo terciopelo que el manto, el cuerpo y las mangas salpicados de flores de lis, con el forro de armiño y ornados de diamantes. La mitad inferior del vestido, corto y de terciopelo violeta, con una franja de armiño alrededor del bajo y una banda ancha por delante, decorada con diamantes, más otra a cada lado con tres filas de flores de lis y otra igual abajo, alrededor de la falda. Las medias eran de seda violeta salpicadas de flores de lis bordadas en oro; los zapatos, de satén violeta, bordados en flores de lis de oro. El traje de María Luisa reflejaba la situación transicional de la novia: nieta de Francia por nacimiento, hija de Francia en la ceremonia y, finalmente, reina de Españ $a^{28}$. Por un lado, el vestido dejaba patente el origen dinástico de la princesa de Orleans y expresaba el status que el rey de Francia le reconocía en la ceremonia. El principal emblema de la dinastía, la flor de lis, cubría el manto, el vestido y las medias. Luis XIV permitió a su sobrina que el traje nupcial fuera bordado con tres filas de flores de lis, prerrogativa que era exclusiva para las hijas de Francia (filles de France) y no así para las princesas de sangre (princesses $d u$ sang de France). Las tres filas de flores de lis bordadas en el vestido de bodas de María Luisa, una princesa de sangre por nacimiento, comunicaban visualmente a toda la corte francesa que la novia contaba con la gracia del rey de Francia. Por otra parte, podemos apreciar que la joven soberana llevaba en la cabeza una «corona [que] era de oro con una

25. Relación verdadera del Real Desposorio de nuestro católico monarca don Carlos II (que Dios guarde) con la reina nuestra señora doña María Luisa de Borbón, celebrado el día 31 de agosto deste presente año de 1679 en el Real Sitio de Fontainebleau. En, Biblioteca Nacional de España [BNE], Mss/14800, ff.423-424.

26. Mercure Galant, octubre de $1679,2^{\circ}$ parte, pp. 78-82. Disponible online en www. gallica.bnf.fr [Fecha de consulta: 10/03/2017] Sobre el Mercure véase NELSON BEST, K.: The History of Fashion Journalism. London and New York, 2017. VINCENT, M.: Le Mercure Galant. Présentation de la première revue féminine d'information et de culture, 1672-1670. París, 2005.

27. Antoine Trouvain, María Luisa de Orleans, c. 1679, grabado 125 x 253 mm. Madrid, Biblioteca Nacional de España. El grabado muestra a la reina de pie, manto extendido y corona real, traje con el que celebró sus desposorios. Véase anexo 1.

28. STERNBERG, G.: Status Interaction during the Reign of Louis XIV. Oxford, 2014. ZANGER, A.: Scenes from the Marriage of Louis XIV: Nuptial Fictions and the Making of Absolutist Power. Stanford, 1997. 
cruz de diamantes y con la forma de la corona de España». El dato de la forma de la corona no es menor. En primer lugar, señalaba su nueva identidad como reina de España. En segundo lugar, demuestra que aquella ceremonia de matrimonio implicó también una entronización ${ }^{29}$. En efecto, el traje de María Luisa no era un verdadero traje de bodas, sino que se parece mucho más al traje que utilizaban las princesas de su rango en ceremonias de coronación. De aquella boda no sólo saldría una esposa para Carlos, nacía también una reina para España.

El príncipe de Contí, en representación de Carlos II, vistió un traje negro decorado con perlas y diamantes en consonancia con el estilo español. El embajador de España, llevaba también un traje «a la española» bordado en hilos de oro y con botonadura de diamantes ${ }^{30}$. Simultáneamente en Madrid, los Grandes y Títulos del reino se presentaron con sus soldados para dar el parabién al rey Carlos. Llamó la atención el atuendo de los lacayos «pues unos vestían a la española, otros a la francesa e italiana e otros a la tudesca, y muchos al africano traje» ${ }^{31}$. Según el cronista, estos tipos de trajes formaban «gallardas y entretenidas representaciones». Por lo tanto, los lacayos que se presentaron ante el rey con estos atuendos tan particulares quizá formaron parte de alguno de los espectáculos, desfiles o entremeses ofrecidos en honor al soberano.

Antes de que María Luisa emprendiera su viaje a la corte española, el marqués de los Balbases le ofreció en París una fiesta en su honor ${ }^{32}$. A ella asistió la joven reina vestida a la francesa y acompañada de sus altezas reales, la duquesa de Mompensier, la señora condesa de Soisson, la princesa de Baden, las duquesas de Foix, de Sully, de la Ferte, de Brachano y muchas otras damas. El 20 de septiembre la petite mademoiselle abandonó París. Iba acompañada por el príncipe de Harcourt, encargado de efectuar la entrega en la Isla de los Faisanes, y un pequeño séquito de servidores franceses. En el número del mes de noviembre de 1679, el Mercure relataba que mientras la reina viajaba por el interior de Francia, no eran pocos los españoles que se acercaban a saludarla. Los más astutos, eligieron ir vestidos «a la francesa» porque sabían que eso agradaba mucho a la reina ${ }^{33}$.

29. GENNEP, A. V.: Los ritos de paso. Madrid, 2008, pp. 198-199.

30. «M. de los Balbases avoit un Habit a l'espagnole, brodé d'or, avec des Boutonnières à queues, dans lesquelles il y avoit de gros diamans». En, Mercure Galant, pp. 88-89.

31. Relación verdedera del Real desposorio de nuestro católico monarca don Carlos II (que Dios guarde) con la reyna nuestra señora doña María Luisa de Borbón..., Academia de la Historia [RAH], 9/3653, f.3.

32. Relación de la fiesta que el excelentísimo marqués de los Balbases, embajador extraordinario del rey nuestro señor (Dios le guarde) a SM Cristianísima dio a la reina nuestra señora Doña María Luisa de Borbón... Madrid, Imprenta de Bernardo Villa-Impresor de SM, 1679.

33. Mercure Galant, noviembre de 1679, pp. 247. 
Un problema de protocolo entre el marqués de los Balbases y el príncipe de Harcourt, vinculado a quien debía colocarse a la derecha de la reina y entregarla a su mayordomo mayor, retrasó la ceremonia de entrega que inicialmente estaba prevista para el 31 de octubre. En la tarde del 3 de noviembre el embajador español cruzó antes la frontera para soslayar el problema y el príncipe de Harcourt acompañó a María Luisa a la Isla de los Faisanes, sobre el río Bidasoa, donde tuvo lugar la ceremonia de entrega oficial. El mayordomo de la reina de España, el marqués de Velada y Astorga, vestido con un traje delicado bordado al estilo español, recibió a la joven reina que por entonces lucía un vestido «bordado de oro y guarnecido de diamantes, el jubón, los calados y la media manguilla y un collar de diamantes y joya grande de los mismo y muchos clavos» ${ }^{34}$. Como ha indicado Anne J. Cruz, la mujer entregada en matrimonio abandonaba a su familia de origen, su país, su lenguaje y su cultura $a^{35}$ En el momento de la entrega oficial se aceleraba la metamorfosis: la joven francesa debía abandonar su identidad de origen al mismo tiempo que debía adquirir la de su marido y sus súbditos ${ }^{36}$. El cambio identitario debía tener una manifestación visible y, por lo tanto, la imagen de la reina debía exteriorizar la transformación esperada por todos. María Luisa no hablaba español todavía y esto era una gran dificultad que impedía que los españoles pudieran tener una identificación con su reina. En consecuencia, se hizo una fuerte apuesta por la imagen de la reina. El cambio del traje suponía un rito de admisión: la adquisición de una nueva identidad tornaba necesario el desposeimiento del yo de origen, simbolizado por el abandono del traje, para convertirse en una posesión del esposo. El nuevo aspecto indumentario de la reina permitiría materializar la integración de la joven en el cuerpo político de la monarquía hispana. Las encargadas de supervisar el proceso de hispanización de las princesas extranjeras en la corte del monarca hispano fueron las camareras mayores de Palacio ${ }^{37}$. En el período que nos ocupa, doña Juana de Aragón y Cortes, duquesa de Terranova, se desempeñó en la jefatura de la cámara de la reina entre

34. En la Biblioteca Nacional de España se conserva el manuscrito 7862 titulado Relación de la jornada que se bizo el dia... del Mes de Seppre. Año de 1789...y subcesos de ella en las Rs Entregas de la Reyna nuestra señora doña María Luisa de Orleans, hija de los serenísimos señores y duques de Olreans, escrito por Joseph Alfonso Guerra y Villegas, ayuda de la furriera de cámara, que viajó acompañando a la reina. El manuscrito fue publicado por LÉONARDON, H.: «Relation du voyage fait en 1679», Bulletin Hispanique, 4, 1902, p. 253.

35. CRUZ, A. J.: «Introduction» in STAMPINO, M. G. and CRUZ, A.J. (eds.): Early Modern Habsburg Women. Transnational contexts, Cultural Conflicts, Dynastic Continuities. New York, 2016, p. 5.

36. Los viajes de boda de las princesas y sus implicaciones en la Europa moderna han sido estudiados por PÉREZ SAMPER, M. A.: «Princesas en camino», Estudis. Revista de Historia Moderna, 39, 2013, pp. 9-41.

37. LOPEZ CORDÓN CORTEZO, M. V.: «Entre damas anda el juego: las camareras mayores de Palacio en la Edad moderna», Cuadernos de Historia Moderna. Anejos, 28, 2003, pp.

Ediciones Universidad de Salamanca / 요 Stud. his., H. ${ }^{a}$ mod., 41, n. 1 (2019), pp. 353-377 
1679 y 1680 . La duquesa era una mujer de edad avanzada conocida por su carácter autoritario y su apego hacia la etiqueta palatina ${ }^{38}$.Esta inflexibilidad provocó decenas de conflictos con su señora. La duquesa reprendió a María Luisa por incumplir los usos y costumbre de España en varias ocasiones y esto disgustó a la reina ${ }^{39}$. En agosto de 1680, María Luisa solicitó a su marido que la duquesa fuera destituida y así se hizo ${ }^{40}$. Con el licenciamiento de la Terranova, María Luisa demostraba que no era un sujeto político pasivo en la corte de Carlos II y que su voz era escuchada por su marido. La nueva camarera mayor, la duquesa Juana de Armendáriz y Ribera, fue más perspicaz que su antecesora y privilegió el buen vínculo con María Luisa por sobre el cumplimiento de la etiqueta. Como tendremos ocasión de demostrar, durante el tiempo que Juana de Armendáriz y Ribera fue camarera mayor de la reina (1680-1689), se permitió a la soberana tomarse ciertas licencias que afectaron la configuración de su real imagen y que hicieron más placentera su vida en la corte.

A pesar de que la reina ingresó a España el 3 de noviembre de 1679, es importante destacar que ni ella ni su corte adoptaron inmediatamente el traje español, tal como lo exigía la etiqueta. Entre el 3 de noviembre y el 11 de noviembre María Luisa hizo varias apariciones públicas en el norte de España «vestida a la francesa» ${ }^{41}$. El domingo 5 de noviembre «su majestad salió a los balcones de la posada mas de dos oras, dejándose ver por todos, vestida a la francesa, con un vestido bordado de plata, su sombrero negro con plumas blancas» ${ }^{42}$. El cuidado de su cabello fue confiado a Madeimoselle de Grancey, Louise-Élizabeth de Rouxel. El día 6 del corriente, la reina se reúne con un grupo de franceses y francesas para jugar a los naipes. Todos lucen diseños franceses, cenan platillos sofisticados y escuchan un concierto ofrecido por los músicos que acompañaban a la soberana en su viaje ${ }^{43}$. No sólo la reina viste a la francesa, sino también buena parte de sus servidores y visitantes. Su caballerizo

123-152. SIMÓN PALMER, M. C.: «Notas sobre las vidas de las mujeres en el Real Alcázar», Cuadernos de Historia Moderna, 19, 1997, pp. 21-37.

38. Madame d'Aulnoy nos ofrece un retrato de la duquesa de Terranova en sus memorias: «Elle est puissamment riche, son humeur est fiere et impérieuse avec les personnes qui sont au-dessus d'elle (...) elle est froide et sérieuse, gardant la gravité espagnole, sans faire un pas ni une demarché qui ne soient compassés; elle parle peu, et dit un. Je le veux, ou. Je ne le veux pas, à faire trembler». D'AULNOY, M.: Mémoires de la cour d'Espagne, Paris, 1902, p. 59.

39. MAURA Y GAMAZO, G.: Vida y reinado de Carlos II, t. I. Madrid, 1954, pp. 337-340.

40. AGP, Personal, C. 109, exp. 29. Para profundizar los motivos que llevaron a la destitución de la duquesa de Terranova y la elección de una nueva camarera mayor, véase mi artículo «The Royal Household of Marie Louise of Orleans, 1679-1689: the Struggle over Executive Offices», The Court Historian, 23/2, 2018, pp. 173-177.

41. LÉONARDON, «Relation du voyage...», pp.340-342.

42. LÉONARDON, «Relation du voyage...», p. 342.

43. En la comitiva francesa de María Luisa se contabilizan 40 músicos. AGP, Reinado de Carlos II, C. 98, exp. 1. Sobre esto véase BENOIT, M.: «Les musiciens français de MarieLouise d'Orleans, Reine d'Espagne» Revue Musicale, 226, 1955, pp. 48-60.

Ediciones Universidad de Salamanca / @®@@ Stud. his., H. ${ }^{a}$ mod., 41, n. 1 (2019), pp. 353-377 
mayor, el duque de Osuna, acompañó a su majestad a una misa en la Iglesia de Irún «vestido maravillosamente a la francesa» ${ }^{44}$. El día 9, la reina llegó a la villa de Oñate donde se encontró con el marqués de Almazán quien «yba vestido a la francesa» ${ }^{45}$.

María Luisa postergó la adopción del traje español hasta el 11 de noviembre, día en que se hizo ver públicamente por primera vez vestida a la española. El Mercure publica, un mes después, que en aquella jornada la reina «prit un Hábit á l'espagnole» ${ }^{46}$. En sus memoires, madame d'Aulnoy reconoce que a la reina le sentaba tan bien el traje español como el francés ${ }^{47}$. En la edición de enero de 1680 , el Mercure señalaba que progresivamente la reina iba abandonando la moda francesa en favor de la española. Según el autor, los españoles empezaron desde entonces a considerarla verdaderamente su reina ${ }^{48}$. No obstante, la hispanización de la imagen de la reina avanzaba con altibajos ya que María Luisa no renunciaba completamente a las influencias francesas. Mediante el uso de trajes y telas francesas, la reina dejaba patente su ascendencia ante los personajes destacados que se acercaban a saludarla. Inmediatamente el día después de que se la había visto ataviada con su traje español, el 12 de noviembre, los contemporáneos volvieron a ver a su reina «vestida a la francesa con muchos diamantes y el pelo puesto a rizos en forma de guirnaldas y a trecho muchos clavos de piedras muy preciosas, brazaletes de lo mismo y una gargantilla de perlas» ${ }^{49}$. La especialista María Teresa Zapata Fernández de la Hoz afirma que por entonces, «la reina seguía vistiendo a la francesa ${ }^{50}$. Por aquellos días, la reina había enviado como obsequio a su esposo una corbata de un rico punto de Francia y un reloj guarnecido de piedras preciosas. Dicha corbata la lucirá el rey posteriormente en un retrato a cuerpo entero realizado por Juan Carreño de Miranda en $1681^{51}$. Para la investigadora Corinne Thépaut-Cabasset, el hecho de que la corbata con un prendedor fuego apareciera en las representaciones iconográficas de Carlos II demuestra la enorme influencia de la reina en la introducción de la moda francesa en la corte de España ${ }^{52}$.

44. LÉONARDON, «Relation du voyage...», p. 253.

45. LÉONARDON, «Relation du voyage...», p. 344.

46. Mercure Galant, diciembre de 1679, p. 291.

47. D’AULNOY, M.: Mémoires..., p. 247.

48. Mercure Galant, enero de 1680, II, p. 132.

49. LÉONARDON, «Relation du voyage...», p. 346.

50. ZAPATA FERNÁNDEZ DE LA HOZ, M. T.: La entrada en la Corte de María Luisa de Orleans: arte y fiesta en el Madrid de Carlos II. Aranjuez-Madrid, 2000, p. 43.

51. Juan Carreño de Miranda. Carlos II con su armadura, 1681, óleo sobre lienzo 232 x $1.25 \mathrm{~cm}$, Madrid, Museo del Prado. Anexo 2. Sobre Carreño de Miranda véase PÉREZ SÁNCHEZ, A.: Juan Carreño de Miranda (1614-1685). Avilés, 1985.

52. THÉPAUT-CABASSET, C.: «María Luisa de Orleans, reina de España», en COLOMER, J. L y DESCALZO, A (dirs.): Vestir a la española en las cortes europeas (siglos XVI y XVII). Madrid, 2014, pp. 267-292. 
El 18 de noviembre de 1679, los novios finalmente se encontraron en la localidad de Quintanapalla (Burgos) y allí ratificaron el enlace matrimonial ante don Antonio de Benavides y Bazán, Patriarca de Indias. La marquesa de Villars y el Mercure coindicen en señalar que María Luisa recibió por primera vez al monarca español vestida con un hermoso traje a la francesa y adornada con una gran cantidad de piedras preciosas ${ }^{53}$. Sin embargo, luego de una pequeña entrevista con el rey, ella y sus damas aparecieron en la ceremonia religiosa vestidas a la español ${ }^{54}$. El rey estaba vestido a la Schomberger, muy similar al estilo francés. Así lo recuerda la condesa d'Aulnoy:

[El rey] llevaba una casaca muy corta y muy ancha, de camelote gris, calzas de terciopelo, medias de seda cruda trabajada tan floja que al través de ella se ve el calcetín, formando un tejido tan fino como si fuera de cabello, y al rey le gusta ponérselas de un tirón, aun cuando estén muy justas, de suerte que algunas veces rompe hasta veinte pares. Llevaba una preciosísima corbata que la reina le había enviado; pero estaba anudada con demasiado abandono. Sus cabellos caían por detrás de las orejas, y llevaba un sombrero gris blanquecino, y vestido él como descrito queda y ella como dije, a la española, siguieron todo el viaje, que era bastante largo, uno frente a otro, en su gran carroza, no pudiendo apenas entenderse sino por algunas acciones, pues el rey no sabe absolutamente nada el francés y la reina hablaba poco la lengua española ${ }^{55}$.

El 20 de noviembre los reyes entraron a Burgos ${ }^{56}$. Si bien en la aparición pública el Mercure indica que la reina iba vestida y peinada a la española, un poema manuscrito, que se conserva en la Biblioteca Nacional de España, sugiere que la reina llegó a la ciudad con atuendos franceses y luego se cambió para presentarse, como la etiqueta lo exigía, vestida como una reina de España. Tal vez no habrían sido tan exageradas las recomendaciones de la duquesa de Terranova, que tanto molestaban a la joven soberana, en relación a mantener las cortinas cerradas de las carrozas para no ser vista, cuando no era debido, por sus súbditos: «viendo entrar a nuestra reina a la francesa (...) pues con trage francés y alma española (...) que el trage era de allá y ella de España $\aleph^{57}$. Finalmente, el 2 de diciembre los reyes entraron en Madrid y, cuarenta y dos días después, la reina hizo su presentación pública. En la arquitectura

53. VILLARS, M. de.: Lettres de Madame de Villars à Madame de Coulanges (16791681). Paris, 1868, p. 86. Mercure Galant, enero de 1680, p. 248. El atuendo francés de la reina es mencionado también ZAPATA FERNÁNDEZ DE LA HOZ. M. T.: La entrada en la Corte..., p. 44.

54. MAURA Y GAMAZO, G.: Vida y reinado..., p. 341.

55. D’AULNOY, M.: Relation du voyage d' Espagne. Paris, 1691, p. 227.

56. Mercure Galant, enero de 1680, pp. 200-202.

57. Relación en ovillejo de lo sucedido a un criado de su Majestad el rey nuestro señor Carlos Segundo (que Dios guarde) en el viaje que se hizo a la ciudad de Burgos, al recibimiento de

Ediciones Universidad de Salamanca / అ@@ Stud. his., H. ${ }^{a}$ mod., 41, n. 1 (2019), pp. 353-377 
efímera erigida para dar la bienvenida a la reina, se resumía lo que de María Luisa se esperaba: el fortalecimiento de la paz con Francia, la prosperidad, la felicidad matrimonial y el deseo de una pronta descendencia ${ }^{58}$. Aquel día, María Luisa fue ataviada como una auténtica reina de España. Por fortuna, en el Ayuntamiento de Toledo se conserva un retrato ecuestre de María Luisa, pintado por Francisco Rizi, que nos proporciona información sobre cómo estaba vestida la reina el día de su entrada pública en Madrid ${ }^{59}$. A esta fuente iconográfica, sumamos los relatos de la época que son coincidentes con lo que vemos en la imagen de Rizi.

Llevaba un precioso vestido de riquísima tela anteada, todo bordado de plata y oro de inestimable valor; y en su Real pecho un aderezo de Diamantes, y en su vuelta del sombrero llevaba la Perla Margarita, que llaman la Peregrina, la cual se pescó el año de 1515 en el Mar del Sur, junto al Darien, en la isla de Terarequi (...) También llevaba su Majestad un anillo, y en él, el Diamante Grande de nuestro rey, que es de fondo cuadrado, y cabal de esquinas, tiene 58 quilates y tiene la misma circunstancia de ser único e inestimable ${ }^{60}$.

La saya que utilizó María Luisa el día de su entrada en la corte se confeccionó en tafetán encarnado con bordados que cubrían toda la tela dibujando diferentes ramos. El color rojo permitía continuar con la tradición de sayas en color encarnado que se había iniciado con Isabel de Borbón y que continuó Mariana de Austria ${ }^{61}$. Por otra parte, cómo podemos apreciar en la pintura antes mencionada, la reina María Luisa lucía un peinado sencillo, con el cabello sin rizos que caía libremente sobre sus hombros. Aunque Madame d'Aulnoy sin duda exagera al escribir que la duquesa de Terranova se escupía las manos para humedecérselas y poder así planchar los rebeldes rizos naturales de su señora, es correcto afirmar que públicamente María Luisa utilizaba el típico peinado español de la década de 1680 con el pelo levemente rizado y una onda tapando parcialmente la frente. Así lo demuestran dos retratos de Juan Carreño de Miranda: uno de cuerpo entero conservado en la antesala del Monasterio de Guadalupe y otro de medio cuerpo de la colección Granados ${ }^{62}$. Sin

María Luisa de Borbón. Refiere las fiestas que bizo la dicha ciudad a la entrada de su Majestad, $y$ otras particularidades, que pasaron en el camino. En, BNE, Mss/3671, f. 399.

58. ZAPATA FERNÁNDEZ DE LA HOZ. M. T.: La entrada en la Corte...,pp. 75-195.

59. Francisco Rizi, María Luisa de Orleans a caballo, 1680, óleo sobre lienzo 344 x 312,5 $\mathrm{cm}$. Toledo, Ayuntamiento de Toledo. Anexo 3.

60. Descripción verdadera y puntual de la Real, Majestuosa y pública entrada, que hizo la reina María Luisa de Borbón desde el Real Sitio del Retiro, hasta su Real Palacio, el sábado 13 de enero deste año de 1680. En, BNE, Mss/3927, ff.17-18.

61. ZAPATA FERNÁNDEZ DE LA HOZ, M. T.: La Corte de Felipe IV se viste de fiesta. La entrada de Mariana de Austria (1649). Valencia, 2017, p. 20, nota ${ }^{\circ} 9$.

62. Juan Carreño de Miranda, María Luisa de Orleans, 1683, óleo sobre lienzo 210 x 175 cm. Cáceres, Monasterio de Guadalupe. Ibídem, María Luisa de Orleans, c.1680, óleo sobre 
embargo es sabido que en la intimidad la joven oponía algunas resistencias al rizado completo de su cabello. El 21 de marzo de 1680, Madame de Villars escribió que en su última visita al Alcázar la reina tenía el cabello sobre la frente, recogido en grandes rizos como usaba cuando vivía en Francia y con cintas de color rosa. Villars destaca que ese día, además, la reina vistió una bata francesa ${ }^{63}$.

Establecida ya en la corte, se aceleró el proceso de hispanización de la imagen de la reina María Luisa quien tuvo que adaptarse a la moda española. El catálogo del Museo Nacional del Prado incluye un retrato de la reina, de medio cuerpo, vestida con un traje de terciopelo rojo floreado, luciendo un diamante y una inusual perla, peinada raya en medio, con un clavel en una mano y un abanico en la otra ${ }^{64}$. Un retrato casi idéntico aparece en las colecciones del Palacio checo Rychnov ${ }^{65}$. A través de ambas obras y de varios relatos contemporáneos, se transmite la idea de una reina hispanizada. Madame de Villars relataba que los cambios en la indumentaria de la reina habían contentando a todos los hombres y mujeres de la corte ${ }^{66}$. En la pintura de José García Hidalgo la imagen de la reina tiene un carácter marcadamente hispano y, de acuerdo con Álvaro Pascual Chenel, responde a la iconografía y modelo habitual para las reinas regentes de la Casa de Austria ${ }^{67}$.

El peinado raya en medio, con el cual es representada María Luisa en la pintura de García Hidalgo, era característico de la moda española a fines del siglo XVII. Este tipo de peinados contrasta enormemente con las representaciones francesas de María Luisa, en sus años juveniles, cuando la princesa utilizaba el pelo suelto y rizado $^{68}$. En lo referente a su aspecto indumentario, es importante señalar que la soberana es representada con un vestido rojo, el color característico de las reinas de España. Sobre el pecho de la reina se aprecia el llamado «joyel rico de los Austrias»

lienzo 102 x $83.2 \mathrm{~cm}$. Madrid, Colección Granados.

63. VILLARS, M. de.: op cit; pp. 118-122.

64. José García Hidalgo, María Luisa de Orleans, 1680, óleo sobre lienzo 96 x 68 cm. Madrid, Museo del Prado. Anexo 4.

65. José García Hidalgo, María Luisa de Orleans, 1680, óleo sobre lienzo 96.5 x $78 \mathrm{~cm}$. Bohemia del Este, Palacio Rychnov. Anexo 5. El estudio comparativo de estas obras ha sido realizado en STEPANEK, P.: «Un retrato de María Luisa de Orleans, de José Hidalgo, en el Prado», Boletín del Museo del Prado, vol. 6, n¹6, 1985, pp. 33-35.

66. VILLARS, M. de.: op cit; pp. 110-111.

67. PASCUAL CHENEL, A.: «Entre regentes y consortes. Mujer, poder y cultura política en el retrato de las reinas de la Monarquía de España durante la Edad Moderna» en BRAZO LOZANO, C y QUIRÓS ROSADO, R (eds.) La corte de los chapines. Mujer y sociedad política en la Monarquía de España, 1649-1714. Milán, 2018, p. 268.

68. Louis le Vieux, María Luisa de Orleans, 1675, óleo sobre lienzo, 81 x $64 \mathrm{~cm}$. Châteaux de Versailles et de Trianon. Anexo 6. En los años iniciales de su infancia, aparece retratada junto con su padre en Pierre Mignard, Felipe de Francia, duque de Orlans, con un retrato de su bija María Luisa, siglo XVIII, óleo sobre lienzo, 150 x $178 \mathrm{~cm}$. Versalles, Châteaux de Versailles et de Trianon. 
compuesto por el diamante denominado El estanque y la perla conocida como La peregrina. Desde que Felipe II obsequió aquél rico joyel a su esposa Isabel de Valois, en lo sucesivo, todas las reinas habían sido representadas en la línea tradicional del retrato aúlico español luciendo el mencionado brillante de 100 quilates y la inusual perla. La reina Ana de Austria luce el joyel en el retrato realizado por Alonso Sánchez Coello con motivo de su boda ${ }^{69}$. Posteriormente, posa para Antonio Moro y Bartolomé González con el diamante montado sobre un águila bicéfala bajo la que cuelga La peregrina ${ }^{70}$. En el siglo XVII, Margarita de Austria posa con el joyel para los retratos de Diego de Velázquez, Juan Pantoja de la Cruz y Bartolomé González ${ }^{71}$. Su esposo, el rey Felipe III, también se muestra usando La peregrina en el retrato ecuestre que Velázquez le realizó para ser colocado en el Salón de Reinos ${ }^{72}$. La reina Isabel de Borbón aparece vistiendo el joyel en la pintura de Rodrigo de Villadrando y en el retrato ecuestre de Velázquez ${ }^{73}$. Este último también pintó a la reina Mariana de Austria luciendo un vestido rojo y portando La peregrina en su tocado ${ }^{74}$.

Por último, la soberana es retratada con un abanico, elemento de origen oriental pero fuertemente instalado en España y, por lo tanto, un objeto con una fuerte marca identitaria. No son pocas las representaciones estéticas conservadas de la reina Isabel de Borbón, incluso el afamado retrato realizado por Velázquez en 1625, en los cuales la reina es retratada sosteniendo un abanico ${ }^{75}$. Tanto María Luisa de Orleans como Isabel de Borbón tuvieron un origen en común ya que eran princesas de Francia. Sylvéne Édouard ha estudiado el caso de la reina Isabel de Valois, también francesa de nacimiento, y arribó a la conclusión de que al momento de su muerte el proceso

69. Alonso Sánchez Coello, Ana de Austria, 1571, óleo sobre lienzo 173,5 x 108, 8 cm. Madrid, Museo Lázaro Galdiano.

70. Antonio Moro, Ana de Austria, 1570, óleo sobre lienzo 161 x $110 \mathrm{~cm}$. Viena, Kunsthistorisches Museum. Bartolomé González según A. Moro, La reina Ana de Austria, cuarta esposa de Felipe II, 1616, óleo sobre lienzo 108,5 x $87 \mathrm{~cm}$. Madrid, Museo del Prado.

71. Diego de Velázquez, La reina Margarita de Austria, a caballo, 1635, óleo sobre lienzo 297 x 212 cm. Madrid, Museo del Prado. Juan Pantoja de la Cruz, Margarita de Austria, 1606, óleo sobre lienzo 207 x $122 \mathrm{~cm}$. Madrid, Museo del Prado. Bartolomé González, La reina doña Margarita de Austria, 1609, óleo sobre lienzo 116 x $100 \mathrm{~cm}$. Madrid, Museo del Prado.

72. Diego de Velázquez, Felipe III, a caballo, 1635, óleo sobre lienzo 300 x $212 \mathrm{~cm}$. Madrid, Museo del Prado.

73. Rodrigo de Villandrando, Isabel de Borbón, esposa de Felipe IV, 1620, óleo sobre lienzo 201 x $115 \mathrm{~cm}$. Madrid, Museo del Prado. Diego de Velázquez, La reina Isabel de Borbón, a caballo, 1635, óleo sobre lienzo 301 x $314 \mathrm{~cm}$. Madrid, Museo del Prado.

74. Diego de Velázquez, Mariana de Austria, c.1655-1660, óleo sobre lienzo 128,5 x 99 $\mathrm{cm}$. Viena, Kunsthistorisches Museum.

75. Diego de Velázquez, Isabel de Borbón, 1625, óleo sobre lienzo 207 x 119 cm. New York, colección particular.

Ediciones Universidad de Salamanca / 요 Stud. his., H. ${ }^{a}$ mod., 41, n. 1 (2019), pp. 353-377 
de hispanización de la imagen de la soberana había concluido exitosamente ${ }^{76}$. En la pintura de García Hidalgo, la esposa francesa de Carlos II sostiene con su mano derecha un clavel de color rojo. El clavel representa la naturaleza principesca de la portadora y, al estar abierto, el pequeño capullo alude a la esperanza de la perpetuación dinástica. En la Monarquía de Carlos II, el complicado estado de salud del rey y la necesidad apremiante del heredero influyeron en la construcción de la imagen de la reina. Gracias a la copia de una pintura atribuida a Francisco Ignacio Ruíz de la Iglesia, sabemos que Carreño pintó un retrato de la reina para ser colgado en el Escorial en el cual se muestra a María Luisa sosteniendo la misma flor ${ }^{77}$. Cuando posteriormente Claudio Coello pinte su ejemplar Mariana de Neoburgo destinado al mismo espacio, seguirá el mismo modelo iconográfico ${ }^{78}$. Todo lo que se esperaba de María Luisa, se exteriorizaba en su atuendo. Sin embargo, recordemos que esta imagen que se proyectaba de la reina y que señalaba el éxito de su integración debe ser contrastada con otros tipos de testimonios.

La correspondencia, las memorias, los libros de cuentas y otras fuentes nos demuestran que la metamorfosis nunca fue completa y que la reina intervino activamente en la construcción de su propia imagen. María Luisa de Orleans se adaptó a la etiqueta española, es cierto, pero paralelamente, se las ingenió para mantener a su lado a su sastre francés Claudio Bretón, continuó utilizando telas y mantos franceses y permitió a sus damas que pudieran vestir diseños similares a los que usaban las mujeres en la corte del rey Cristianísimo. En palabras del duque de Maura, fue el influjo creciente de María Luisa sobre el rey lo que «le permitió transformar a su gusto muchos hábitos de la Corte de España ${ }^{79}$.

En la Real Casa de María Luisa, evidenciamos la presencia de dos sastres que trabajaron al servicio de la reina, uno español y el otro de origen francés. El sastre español Isidro Robledo tuvo que compartir las tareas propias de su oficio con el francés Claudio Bretón, un hombre que formaba parte de la comitiva francesa de la reina al momento de ingresar a la corte ${ }^{80}$. Bretón había trabajado al servicio de la Casa de Orleans en Francia y conocía perfectamente los gustos de la novel soberana. En efecto, en las cuentas del tesorero de la reina se aprecia que era el sastre francés el

76. ÉDOUARD, S.: «Isabel de Valois, hispanizada en la corte de Felipe II», en COLOMER, J. L. y DESCALZO, A. (dirs.): Vestir a la española en las cortes europeas (siglos XVI y XVII), vol. II. Madrid, 2014, pp. 237-260.

77. Francisco Ignacio Ruíz de la Iglesia, María Luisa de Orleans, 1680. Madrid, Museo del Prado.

78. Claudio Coello, Mariana de Neoburgo, 1680. San Lorenzo de El Escorial, Real Monasterio de El Escorial, Patrimonio Nacional.

79. MAURA y GAMAZO, G.: Vida y reinado... p. 347.

80. AGP, Histórica, C. 20. 
encargado de comprar las telas y los accesorios por encargo directo de María Luisa ${ }^{81}$. Madame de Villars, astuta observadora del mundo de la corte, advirtió que a pesar de que la reina vestía a la española, muchos de sus trajes estaban confeccionados con telas que había traído desde Francia: «la jeune reine [...] était habillée a l’Espagnole, des ces étoffes qu'elle a apportées de France» ${ }^{82}$. Madame d'Aulnoy no solamente notó que María Luisa utilizaba telas francesas en sus vestidos, sino también en la ropa de cama. Al respecto, la condesa hace notar que a pesar de que los españoles no tenían la costumbre de utilizar batas mientras se encontraban en la cama, en el guardarropas de la reina había varias batas traídas de Francia ${ }^{83}$.

Corinne Thépaut-Cabasset ha evidenciado que el sentimiento antifrancés en la corte no se hizo extensivo al terreno de la moda ${ }^{84}$. Las damas de María Luisa, hijas de la nobleza española de los más altos linajes, utilizaron trajes franceses en varias ocasiones. En la corte, las damas y meninas vestían del mismo modo y conjuntadas con la reina. Era habitual que utilizaran tejidos similares al de la reina y con tonalidades afines. La esposa del embajador francés Villars relata que la reina Mariana de Austria no sólo no reprobaba esta conducta entre las damas de María Luisa, sino que por el contrario, la favorecía: «la reine mere aime tout á fait l' habit a la francaise, et toutes les dames aussi; c'est-a-dire, les manteaux principalement, et c'est ce que m'accommode fort ${ }^{85}$. Pero, ciertamente, nos equivocaríamos si pensamos que el uso de trajes franceses en la cámara de la reina era algo festejado por todos. Quien mejor expresó la disidencia en este punto fue el embajador Federico Cornaro quien escribió a sus señores que «la reina (...) repugna los modos y las modas de España, lo cual impide conseguir el aplauso general ${ }^{86}$. Entre las gentes del pueblo, estas manifestaciones estéticas de afrancesamiento en el entorno cortesano de la reina generaron un fuerte rechazo y se expresaron en la sátira política ${ }^{87}$. En opinión de Joan Lluís Palos, las mujeres de la realeza que buscaron conservar su identidad

81. AGP, Cuentas del Tesorero de la Reina, 1681-1692, C. 10325.

82. VILLARS, M. de.: op cit; p. 92.

83. D’AULNOY, M.: Relation du voyage..., p. 232.

84. THÉPAUT-CABASSET, C.: op cit, p.281.

85. VILLARS, M. de.: op cit; p. 102. La relación de María Luisa de Orleans con su suegra ha sido estudiada en OLIVÁN SANTALIESTRA, L.: Mariana de Austria en la encrucijada política del siglo XVII, tesis doctoral inédita. Madrid, Universidad Complutense de Madrid, 2006, pp. 405-406.

86. Citado en MAURA Y GAMAZO, G.: María Luisa de Orleans, reina de España. Leyenda e historia. Madrid, s/a, p. 120.

87. El empeño de María Luisa por implantar las modas francesas le granjeó antipatías populares, aspecto que se refleja en la publicista política. Véase GÓMEZ CENTURIÓN, C.: «La sátira política durante el reinado de Carlos II», Cuadernos de Historia Moderna y Contemporánea, 4, 1983, pp. 24-26. 
cultural y crear espacios de autonomía en las cortes de sus esposos fueron, en la mayoría de los casos, muy criticadas por sus contemporáneos:

Despite their efforts to adapt to their new country and to forge cultural links between their natal and their adopted lands (or, perhaps, precisely because of this), many of these women were considered foreigners at their husband's court and were made to endure severe criticism and, on occasion, active opposition. This was the price they had to pay to maintain their composite identities ${ }^{88}$.

Ahora bien, cabe preguntarnos en torno a los motivos que habilitaron a la reina a tomarse ciertas licencias y, fundamentalmente, cuál era el sentido de esto. En la década de 1680, la Francia de Luis XIV se erigía como una de las principales potencias europeas. Cada vez que la reina católica, hija de Monsieur y sobrina del rey Cristianísimo, utilizaba un vestido, un tejido o accesorio francés dejaba patente su calidad personal y les recordaba a todos sus vínculos con la Monarquía francesa. Los contemporáneos supieron descifrar el lenguaje político que se escondía detrás de la elección de ciertas prendas por sobre otras. No es casual que los embajadores recojan este tipo de información y la remitan a sus señores. El caso de María Luisa pone en evidencia como una reina podía lograr individualizarse de una manera ingeniosa sin afectar completamente la etiqueta ni contradiciendo radicalmente el modelo vigente. A inicios del siglo XVII, la italiana María de Médici, reina consorte de Francia con ocasión de su matrimonio con Enrique IV, también se había resistido a adoptar su nueva identidad desposeyéndose completamente de su identidad de origen. La metamorfosis de la segunda esposa de Enrique IV de Francia no fue inmediata. María de Médici no sólo vistió a la italiana en varias ocasiones sino que incluso se hizo representar como italiana en su primer retrato como reina de Francia. Según Dubost, María de Médici adoptó definitivamente el traje francés solamente tras convertirse en madre del delfín de Francia ${ }^{89}$. El 7 de junio de 1660, la española María Teresa de Austria, hija de Felipe IV de España y reina consorte de Francia por su matrimonio con Luis XIV, cruzó la frontera que separaba las monarquías española y francesa e ingresó a la corte de los borbones luciendo un ostentoso guardainfante. A pesar de que María Teresa gradualmente comenzó a adoptar el traje francés, la reina nunca abandonó elementos típicos del traje español. El aspecto indumentario de la reina de Francia combinó elementos culturales provenientes de

88. PALOS, J. L.: «Introduction. Bargaining Chips: Strategic Marriages and Cultural Circulation in Early Modern Europe» in PALOS, J. L and SÁNCHEZ, M (eds.) Early Modern Dynastic Marriages and Cultural Transfer. London, 2016 p. 17.

89. DUBOST. J. F.: «Le simple corps'de la reine de France au debut du XVIIe siècle» in POUTRIN, I. et SCHAUB, M.K. (dir.): Femmes et pouvoir politique. Les princesses d'Europe. xve-xviiie siècles. Paris, 2007, pp. 233-266 
ambas monarquías ${ }^{90}$. En términos comparativos, el estudio de la imagen de María Luisa de Orleans ha puesto de manifiesto esta situación de hibridación cultural expresada en el traje y que se asocia a una renuncia del completo desposeimiento del yo. Solo resta destacar que, a diferencia de sus antecesoras francesas Isabel de Valois e Isabel de Borbón e incluso de su bisabuela María de Medici y su tía María Teresa de Austria, la primera esposa de Carlos II no tuvo descendencia; y por lo tanto es inviable suponer el impacto que la maternidad podría haber supuesto en la configuración de su imagen real.

\section{CONCLUSIÓN}

En tiempos de Carlos II, la monarquía hizo una utilización consciente de la imagen real en pos de la construcción de autoridad soberana. Las imágenes fueron utilizadas para modificar y construir identidades. En este sentido, sostenemos aquí que la imagen real de María Luisa de Orleans, al igual que las regias consortes que la precedieron, fue una construcción cultural ideada políticamente por la monarquía y sustentada a través de un discurso visual. Las imágenes de la reina no fueron inocentes, ni espontáneas, ni realistas. En el terreno de las representaciones estéticas, los distintos retratos que se han hecho de la reina María Luisa de Orleans muestran la imagen de una reina hispanizada. Sin embargo, en este trabajo hemos demostrado que a pesar de que la reina aceptó las costumbres y la moda española, también logró individualizarse dejando patente su ascendencia francesa a través de su vestimenta. La reina exploró en la diversidad alternando el uso de trajes españoles y franceses, tuvo dos sastres de cámara - uno francés y el otro español- que debieron trabajar conjuntamente, continuó comprando telas extranjeras, permitió a sus damas usar trajes franceses, conservó prendas de cama que había traído desde París y logró con astucia manipular a sus camareras mayores para flexibilizar la etiqueta. No hay duda de que María Luisa participó activamente en la construcción de su propia imagen real y se rebeló ante quienes pretendieron asignarle un rol pasivo. El contexto histórico internacional, signado por la hegemonía política y cultural de la Francia de Luis XIV, le permitió a la soberana tomarse ciertas licencias. A través del vestuario, la reina día a día expresaba y reactualizaba posiciones políticas e identidades culturales.

90. VITIS, M. DE.: «The Queen of France and the Capital of Cultural Heritage» in PALOS, J. L and SÁNCHEZ, M (eds.) Early Modern Dynastic Marriages and Cultural Transfer. London, 2016, p. 50. 


\section{ANEXO DE IMÁGENES}

\subsection{María Luisa de Orleans: traje de bodas}

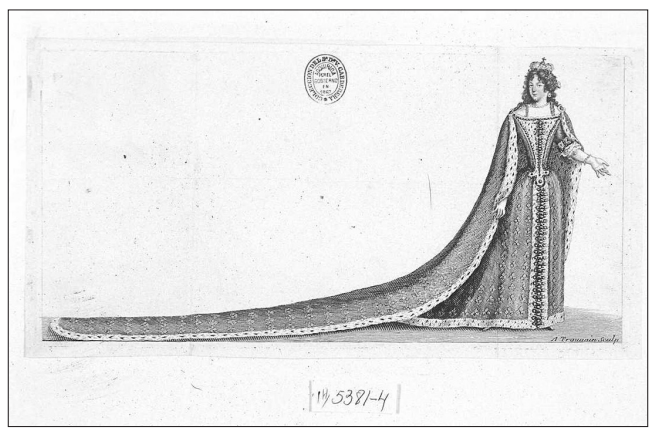

Antoine Trouvain, María Luisa de Orleans, c. 1679, grabado 125 x 253 mm, Madrid, Biblioteca Nacional de España, IH/5381/4.

\subsection{Carlos II con su armadura}

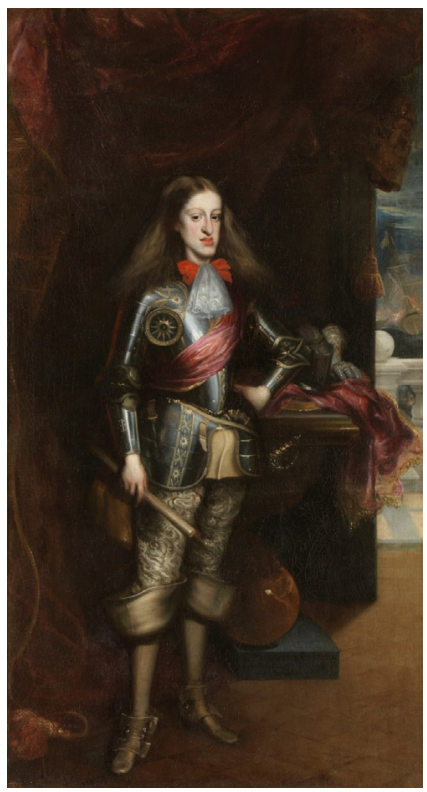

Juan Carreño de Miranda. Carlos II con su armadura, 1681, óleo sobre lienzo 232 × $1.25 \mathrm{~cm}$, Madrid, Museo del Prado, Colección Real, n de catálogo P07101.

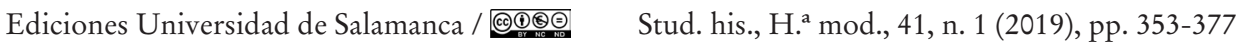




\subsection{María Luisa a caballo}

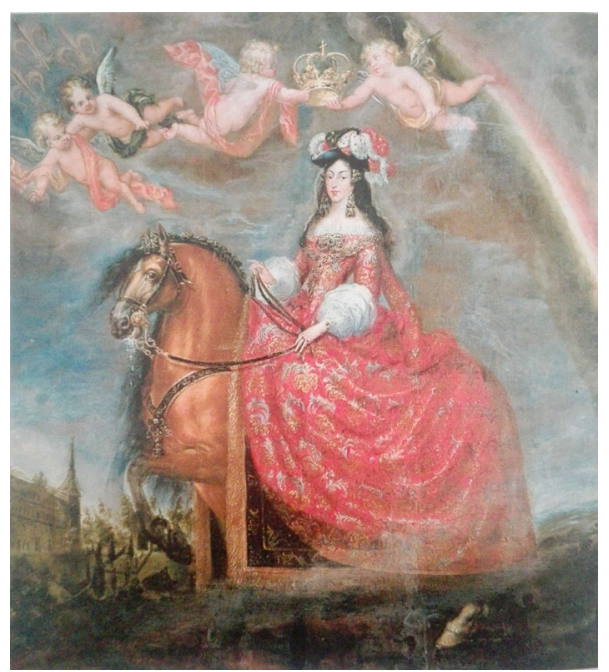

Francisco Rizi. María Luisa de Orleans a caballo, 1680, óleo sobre lienzo 344 x 312,5 cm, Toledo, Ayuntamiento de Toledo.

\subsection{María Luisa, reina de España (Museo del Prado)}

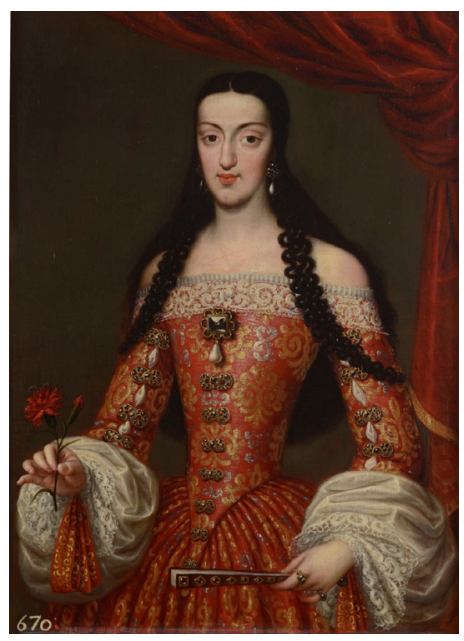

José García Hidalgo. María Luisa de Orleans, 1680, óleo sobre lienzo 96 x 68 cm, Madrid, Museo del Prado, Colección Real, nº de catálogo P00652.

Ediciones Universidad de Salamanca / అ@@ Stud. his., H. ${ }^{a}$ mod., 41, n. 1 (2019), pp. 353-377 


\subsection{María Luisa, reina de España (Palacio Rychnov)}

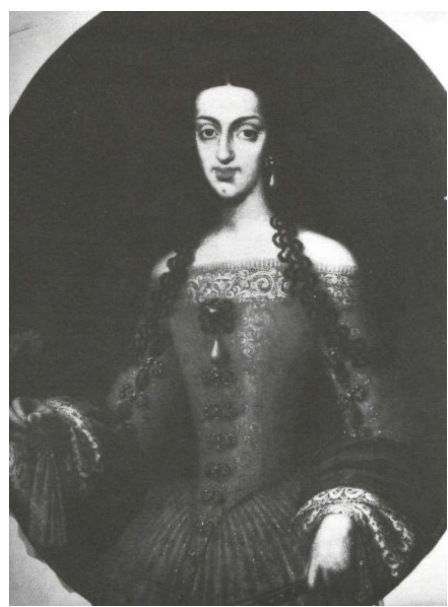

José García Hidalgo. María Luisa de Orleans, 1680, óleo sobre lienzo 96.5 x 78 cm, Bohemia del Este, Palacio Rychnov. La imagen ha sido tomada de Pavel Stepanek, «Un retrato de María Luisa de Orleans, de José Hidalgo, en el Prado», Boletín del Museo del Prado, vol. 6, n¹6 (1985), p 35.

\subsection{Marie-Louise d'Orléans, reine d'Espagne (Châteaux de Versailles et de Trianon)}

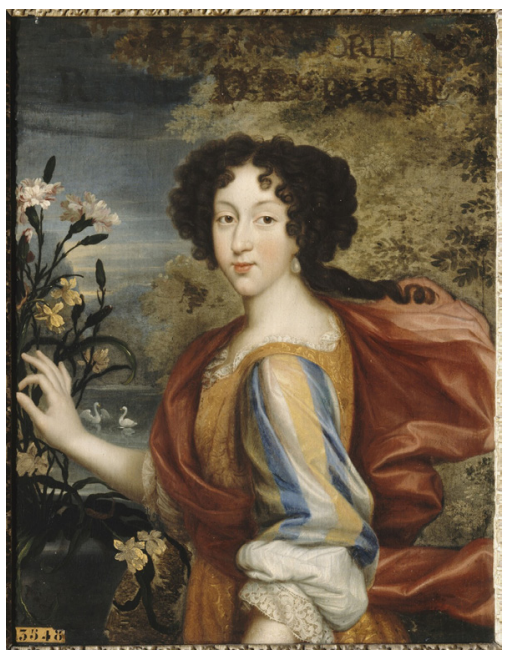

Louis le Vieux. María Luisa de Orleans, 1675, óleo sobre lienzo, 81 x 64 cm. Châteaux de Versailles et de Trianon.

Ediciones Universidad de Salamanca / అ@@ Stud. his., H. ${ }^{a}$ mod., 41, n. 1 (2019), pp. 353-377 
EZEQUIEL BORGOGNONI

LA CONSTRUCCIÓN DE LA IMAGEN REGIA DE MARÍA LUISA DE ORLEANS

\section{BIBLIOGRAFÍA}

ARIBAUD, C. et MOUYSSET, S. (eds.): Vêture et pouvoir: XIIIe-XIXe siècles. Toulouse, Framespa, 2003.

BENOIT, M.: «Les musiciens français de Marie-Louise d'Orleans, Reine d'Espagne» Revue Musicale, 226, 1955, pp. 48-60.

BERNIS, C.: El traje y los tipos sociales en el Quijote. Madrid, Ediciones el Viso, 2001.

BERNIS, C.: «La moda en la España de Felipe II a través del retrato de Corte» en SERRERA, J.M. (ed.): Alónso Sánchez Coello y el retrato en la Corte de Felipe II. Madrid, Museo del Prado, 1991, pp. 66-111.

BERNIS, C.: Trajes y modas en la España de los Reyes Católicos, 2 vols, Madrid, Instituto Diego Velázquez, 1978-1989.

BERNIS, C.: Indumentaria española en tiempos de Carlos V. Madrid, Instituto Diego Velázquez-CSIC, 1962.

BORGOGNONI, E.: «The Royal Household of Marie Louise of Orleans, 1679-1689: the Struggle over Executive Offices», The Court Historian, 23:2, 2018, pp. 173-177.

BOUZA ÁLVAREZ, F.: Palabra e imagen en la Corte. Cultura oral y visual de la nobleza en el Siglo de Oro. Madrid, Adaba, 2003.

BUTTAZZI, G.: «Intorno al Cavalliere in nero: note sulla moda maschile tra Cinquecento e Seicento", in ZANNI, A e DI LORENZO, A (eds.) Giovanni Battista Moroni: Il Cavaliere in nero, Milano, Museo Poldi Pezzoli, 2005, pp. 47-55.

COLOMER, J.L.: «El negro y la imagen real» en COLOMER, J.L y DESCALZO A (dirs.): Vestir a la española en las cortes europeas (siglos XVI y XVII). Madrid, CEEH, 2014, pp. 77-112.

CRUZ, A.J.: «Introduction» in STAMPINO, M.G. and CRUZ, A. J. (eds.): Early Modern Habsburg Women. Transnational contexts, Cultural Conflicts, Dynastic Continuities. New York, Routledge, 2016.

D’AULNOY, M.: Mémoires de la cour d'Espagne. Paris, Collection pour les Jeunes Filles. Choix de Mémoires et Ecrits des Femmes Françaises, 1902.

DESCALZO, A.: «El traje masculino español en la época de los Austrias» en COLOMER, J. L y DESCALZO, A (dirs.): Vestir a la española en las cortes europeas (siglos XVI y XVII). Madrid, CEEH, 2014.

DESCALZO, A.: El retrato y la moda en España (1661-1746), tesis doctoral inédita, Madrid, Universidad Autónoma de Madrid, 2004.

DUBOST, J. F.: «Le simple corps'de la reine de France au debut du XVIIe siècle» in POUTRIN, I. et SCHAUB, M. K. (dir.): Femmes et pouvoir politique. Les princesses d'Europe. xve-xviiie siècles. Paris, Bréal, 2007, pp. 233-266

EARENFIGHT, T.: The King's Other Body. Maria of Castile and the Crown of Aragon. Philadelphia, University of Pennsylvania Press, 2010.

ÉDOUARD, S.: «Isabel de Valois, hispanizada en la corte de Felipe II», en COLOMER, J. L. y DESCALZO, A. (dirs.): Vestir a la española en las cortes europeas (siglos XVI y XVII). Madrid, CEEH, 2014, pp. 237-260.

Ediciones Universidad de Salamanca / @®@@ Stud. his., H. ${ }^{a}$ mod., 41, n. 1 (2019), pp. 353-377 
GENNEP, A. V.: Los ritos de paso. Madrid, Alianza, 2008.

GIORGI, A.: España viste a la francesa. La historia de un traje de moda de la segunda mitad del siglo XVII. Murcia, Universidad de Murcia, 2016.

GÓMEZ CENTURIÓN, C.: «La sátira política durante el reinado de Carlos II», Cuadernos de Historia Moderna y Contemporánea, 4, 1983.

GUARINO, G.: «Modas españolas y leyes suntuarias en la Italia de los Austrias» en COLOMER, J. L. y DESCALZO, A. (dirs.): Vestir a la española en las cortes europeas (siglos XVI y XVII). Madrid, CEEH, 2014, pp. 233-250

HAJNÁ, M.: «Moda al servicio del poder. La vestimenta en la sociedad noble de la Europa Central de la Edad Moderna y la influencia de España» en CABAÑAS BRAVO, M.; LÓPEZ YARTO ELIZALDE, A. y RINCÓN GARCÍA, W. (coords.): Arte, poder y sociedad en la España de los siglos XV a XX. Madrid, CSIC, 2007, pp. 71-82.

JOLIVET, S.: «La construction d'une image: Philippe le Bon et le noir (1419-1467)», Apparence (s), 6, 2015, pp. 1-35.

LÉONARDON, H.: «Relation du voyage fait en 1679», Bulletin Hispanique, 4, 1902.

LLORENTE, M.: «Mariana of Austria's Portraits as Ruler-Governor and Curadora by Juan Carreño de Miranda and Claudio Coello» in CRUZ, A.J. and STAMPINO, M.G. (eds.): Early Modern Habsburg Women: Transnational Contexts, Cultural Conflicts, Dynastic Continuities. Farnham, Ashgate, 2013.

LÓPEZ CORDÓN CORTEZO, M. V.: «Entre damas anda el juego: las camareras mayores de Palacio en la Edad moderna», Cuadernos de Historia Moderna. Anejos, 28, 2003, pp. 123-152.

LOZANO, J.S: «Ser vistas, hacerse mirar. Modelos visuales de feminidad regia en la Europa del Renacimiento» en RÍOS LLORET, R.E; VILAPLANA SANCHIS, S. et all (eds.): Germana de Foix $i$ la societat cortesana del seu temps. Valencia, Generaltat Valenciana, 2006.

MAURA y GAMAZO, G.: María Luisa de Orleans, reina de España. Leyenda e historia. Madrid, Saturnino Calleja, s/a.

MAURA y GAMAZO, G.: Vida y reinado de Carlos II, t. I, Madrid, Espasa Calpe, 1954.

MCGLYNN, S. and WOODACRE, E. (eds.): The Image and Perception of Monarchy in Medieval and Early Modern Europe. Newcastle, Cambridge Scholars Publishing, 2014.

MUÑOZ, A.: Sumaria y verdadera relación del buen viaje que el buen príncipe de las Españas don Felipe hizo a Inglaterra, Zaragoza, Esteban de Nájera, 1554.

NELSON BEST, K.: The History of Fashion Journalism. London and New York, Bloomsbury Academic, 2017.

OLIVÁN SANTALIESTRA, L.: Mariana de Austria en la encrucijada política del siglo XVII, tesis doctoral inédita, Madrid, Universidad Complutense de Madrid, 2006.

PASCUAL CHENEL, Á.: «La construcción visual de la imagen regia durante el reinado de Carlos II. Simulacros de Majestad y propaganda política» en GARCÍA GARCÍA, B y ÁLVAREZ OSSORIO ALVARIÑO, A. (eds.): Visperas de Sucesión. Europa y la Monarquía de Carlos II. Madrid, Fundación Carlos de Amberes, 2015, pp. 297-331.

Ediciones Universidad de Salamanca / @@@ Stud. his., H. ${ }^{a}$ mod., 41, n. 1 (2019), pp. 353-377 
PÉREZ SAMPER, M.A.: «Princesas en camino», Estudis. Revista de Historia Moderna, 39, 2013, pp. 9-41.

PÉREZ SÁNCHEZ, A.: Juan Carreño de Miranda (1614-1685). Avilés, Ayuntamiento de Avilés, 1985.

ROCHE, D.: A History of Everyday Things, Cambridge, Cambridge University Press, 2000.

RODRÍGUEZ DE CEBALLOS, A.: «Retrato de Estado y propaganda política: Carlos II (en el tercer centenario de su muerte)», Anuario del Departamento de Historia y Teoria del Arte, 12, 2000, pp. 93-109.

ROQUERO, A.: Tintes y tintoreros de América: catálogo de materias primas y registro etnográfico de México, Centro América, Andes Centrales y Selva amazónica. Madrid, Ministerio de Cultura, 2006.

SÁNCHEZ ORTIZ, A.: «El color: símbolo de poder y orden social. Apuntes para una historia de las apariencias en Europa», Espacio, Tiempo y Forma, Serie IV, H. Moderna, 12, 1999, pp. 321-354.

SEMPERE y GUARINOS, J.: Historia del lujo y de las leyes suntuarias en España. Madrid, Imprenta Real, 1788.

SIMÓN PALMER, M. C.: «Notas sobre las vidas de las mujeres en el Real Alcázar», Cuadernos de Historia Moderna, 19, 1997, pp. 21-37.

STEPANEK, P.: «Un retrato de María Luisa de Orleans, de José Hidalgo, en el Prado», Boletín del Museo del Prado, vol. 6, n¹6, 1985, pp. 33-35.

STERNBERG, G.: Status Interaction during the Reign of Louis XIV, Oxford, Oxford University Press, 2014.

THÉPAUT-CABASSET, C.: «María Luisa de Orleans, reina de España» en COLOMER, J. L y DESCALZO, A (dirs.): Vestir a la española en las cortes europeas (siglos XVI y XVII). Madrid, CEEH, 2014, pp. 267-292.

VALGOMA y DÍAZ-VARELA, D. de la: Norma y ceremonia de las reinas de la Casa de Austria. Madrid, Real Academia de la Historia, 1958.

VILLARS, M. de.: Lettres de Madame de Villars à Madame de Coulanges (1679-1681). Paris, Henri Plon-Imprimeur, éditeur, 1868.

VINCENT, M.: Le Mercure Galant. Présentation de la première revue féminine d'information et de culture. 1672-1670, París, H. Champion, 2005.

VITIS, M. DE.: «The Queen of France and the Capital of Cultural Heritage» in Palos, J. L and Sánchez, M (eds.) Early Modern Dynastic Marriages and Cultural Transfer, London, Ashgate, 2016, pp. 45-65.

ZANGER, A.: Scenes from the Marriage of Louis XIV: Nuptial Fictions and the Making of Absolutist Power, Stanford, Standford University Press, 1997.

ZAPATA FERNÁNDEZ DE LA HOZ, M. T.: La Corte de Felipe IV se viste de fiesta. La entrada de Mariana de Austria (1649). Valencia, Universitat de València, 2017.

ZAPATA FERNÁNDEZ DE LA HOZ, M. T.: La entrada en la Corte de María Luisa de Orleans: arte y fiesta en el Madrid de Carlos II. Aranjuez-Madrid, Doce Calles, 2000. 
